Published in final edited form as:

Nat Prod Res. 2017 February ; 31(3): 261-267. doi:10.1080/14786419.2016.1230115.

\title{
Cytotoxic Halogenated Monoterpenes From Plocamium cartilagineum
}

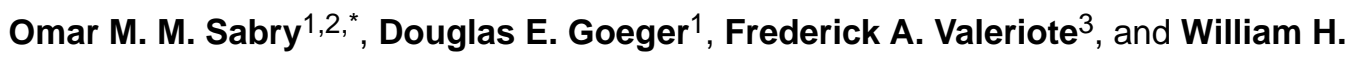 \\ Gerwick $^{1,4}$ \\ ${ }^{1}$ College of Pharmacy, Oregon State University, Corvallis, Oregon 97331, USA \\ ${ }^{2}$ Faculty of Pharmacy, Cairo University, Cairo 11562, Egypt \\ ${ }^{3}$ Division of Hematology and Oncology Department of Internal Medicine, Henry Ford Hospital \\ Detroit, MI 48202, USA \\ ${ }^{4}$ Center for Marine Biotechnology and Biomedicine, Scripps Institution of Oceanography, \\ University of California, San Diego, La Jolla, CA 92093, USA
}

\begin{abstract}
As a result of our efforts to identify bioactive agents from marine algae, we have isolated and identified one new halogenated monoterpene 1 [(-)-(5E,7Z)-3,4,8-trichloro-7-dichloromethyl-3methyl-1,5,7-octatriene] in addition to three known compounds $(2,3$ and 4$)$ from the red alga Plocamium cartilagineum collected by hand from the eastern coast of South Africa. Compound 1 was found to be active as a cytotoxic agent in human lung cancer (NCI-H460) and mouse neuro-2a cell lines ( $\mathrm{IC}_{50} 4 \mu \mathrm{g} / \mathrm{ml}$ ). Two of these compounds ( 3 and $\mathbf{4}$ ) were found to have cytotoxic activity in other cell line assays, especially against human leukemia and human colon cancers $\left(\mathrm{IC}_{50} 1.3 \mu \mathrm{g} /\right.$ $\mathrm{ml}$ ). None of these metabolites were active as sodium channel blockers or activators. All structures were determined by spectroscopic methods (UV, IR, LRMS, HRMS, 1D NMR and 2D NMR). 1D and 2D NOE experiments were carried out on these compounds to confirm the geometry of the double bonds.
\end{abstract}

\section{Keywords}

Halogenated monoterpenes; human lung cancers; human colon cancers; human leukemia; Plocamium Cartilagineum

\section{Introduction}

As a result of their predominant growth in temperate and tropical locations, red algae are among the most frequently investigated sources for marine natural products. They include

Correspondence and requests for materials should be addressed to Omar M. M. Sabry (omar.sabry@cu.edu.eg).

Supplementary material

Supplementary materials relating to this paper are available online.

Disclosure statement

No potential conflict of interest was reported by the authors. 
more than 4000 species distributed in different localities around the world (Gerwick et al., 2001; Rovirosa et al., 2013). Plocamium cartilagineum is a species of red algae (family Plocamiaceae, order Gigartinales). This species is characterized by its interesting secondary metabolites, being a rich source of diverse polyhalogenated monoterpenes, with a surprising degree of halogen incorporation (Young et al., 2013; Inés et al., 2004, Palma et al., 2004, Gao et al., 2001, Norton et al., 1977; Capon et al., 1984; Wright et al., 1990; Mynderse and Faulkner, 1975). Polyhalogenated monoterpenes vary for the given species depending on collection, location and season (Fuller et al., 1992). Research on this genus has yielded a number of halogenated metabolites that display considerable biological activities such as cytotoxic activity (Naylor et al., 1983; Ortega et al., 1997; Wessels et al., 2000; Vogel et al., 2014), anti-feedant activity (Argandona et al., 2002), anti-fungal activity, molluscicidal activity and insecticidal activity (Watanabe et al., 1989). These secondary metabolites can be categorized into two predominant skeletal types, the 2,6-dimethyloctanes and cyclohexanes (Mynderse and Faulkner, 1975; Crews 1977).

\section{Results and discussion}

In our continuing efforts using bioassay guided fractionation to characterize the prolific natural products from marine algae, a detailed examination of the crude organic extract of Plocamium cartilagineum from a South African collection was carried out. After extraction of the alcohol-preserved tissue with $\mathrm{CH}_{2} \mathrm{Cl}_{2} / \mathrm{MeOH}$ (2:1), initial fractionation was accomplished by VLC (EtOAc/hexanes gradient) over silica gel. Successive normal phase HPLC fractionations and purifications resulted in the isolation of one new compound (1), in addition to three previously known compounds 2-4 (Mynderse and Faulkner 1975; Crews 1977). (Figure 1)

Analysis of different spectroscopic data e.g. UV, IR, LRMS, HRMS, 1D NMR and 2D NMR of the isolated compounds allowed construction of the in planar structures. $\mathrm{HMBC}$ and MS fragmentation were used to confirm these statements. ${ }^{1} \mathrm{H}-{ }^{1} \mathrm{H}$ coupling constants, ${ }^{13} \mathrm{C}$ NMR, 1D and 2D NOE were used to confirm the double bond geometry.

Compound 1 showed in the LRCIMS the presence of fragment ion clusters [M-Cl] ${ }^{+}(\mathrm{m} / \mathrm{Z}$ $271,273,275,277),[\mathrm{M}-\mathrm{Cl}-\mathrm{HCl}]^{+}\left(\mathrm{m} / z\right.$ 235, 237, 239, 241) and $[\mathrm{M}-\mathrm{Cl}-2 \mathrm{HCl}]^{+}(\mathrm{m} / z$ 199, 201, 203). HRCIMS showed an ion at $\mathrm{m} / z 305.93079[\mathrm{M}]^{+}$for a molecular formula of $\mathrm{C}_{10} \mathrm{H}_{11} \mathrm{Cl}_{5}$, and therefore possessed three degrees of unsaturation. The IR spectrum of $\mathbf{1}$ showed absorption bands at $2923 \mathrm{~cm}^{-1}$, indicating the presence of an olefinic group functionality. The ${ }^{1} \mathrm{H}$ NMR spectrum in $\mathrm{CDCl}_{3}$ of $\mathbf{1}$ (Table $\mathrm{S} 1$ ) showed signals corresponding to one dihalomethylene group at $\delta_{\mathrm{H}} 6.96(1 \mathrm{H}, \mathrm{s})$ and six olefinic protons at $\delta_{\mathrm{H}} 6.3(1 \mathrm{H}, \mathrm{s}), 6.35(1 \mathrm{H}, \mathrm{dd}, J=17,7 \mathrm{~Hz}), 6.34(1 \mathrm{H}, \mathrm{dd}, J=17,2 \mathrm{~Hz}), 5.41(1 \mathrm{H}, \mathrm{d}, J=17$ $\mathrm{Hz}), 5.29(1 \mathrm{H}, \mathrm{d}, J=11 \mathrm{~Hz})$ and $6.07(1 \mathrm{H}, \mathrm{dd}, J=17,11 \mathrm{~Hz})$. Additionally there was a doublet of doublet at $\delta_{\mathrm{H}} 4.55(1 \mathrm{H}, \mathrm{dd}, J=7,2 \mathrm{~Hz})$, attributed to a mono halomethylene group proton and one methyl group geminal to a halogen atom $\left(\delta_{\mathrm{H}} 1.77,3 \mathrm{H}, \mathrm{s}\right)$. The ${ }^{13} \mathrm{C}$ NMR spectrum of 1 in $\mathrm{CDCl}_{3}$ (Table S1) showed signals for 10 carbons. The numbers of attached hydrogen atoms were determined from the HSQC and HMBC spectra: one methyl at $\delta 25.1$, one methylene, at $\delta 116.0$, six methines (four olefinic at $\delta 140.0, \delta 131.0, \delta 127.0$, $\delta 119.7$ two bearing halogen at $\delta 69.2$ and 66.0), and two nonprotonated carbons at $\delta 138.1$ 
and 72.0 were observed. This was in keeping with the three degrees of unsaturation required by the molecular formula.

Chemical shift arguments and ${ }^{1} \mathrm{H}-{ }^{1} \mathrm{H}$ COSY correlations supported by MS data and HMBC allowed the assignment of fragments "a" and "b" (Figure 2). From the ${ }^{1} \mathrm{H}-{ }^{1} \mathrm{H}$ COSY NMR spectrum of $\mathbf{1}$, it was possible to differentiate two discrete spin systems. The coupling between signals corresponding to the olefinic protons at $\delta$ 5.41, 5.29 and 6.07 established the connectivity of the H-1-H-2 fragment in a. The coupling between one of the protons bearing halogen $(\delta 4.55)$ and the methine protons at $\delta 6.35$ and 6.34 established the connectivity of the $\mathrm{H}-4$ to $\mathrm{H} 6$ in fragment $\mathbf{b}$. HMBC data were used to confirm the remainder of fragment $\mathbf{b}$ from the correlations between $\mathrm{H}-4$ and C-2, C-3, C-5, C-6. The C-5/C-6/C-7 constellation was determined by the correlation between H-6 and C-5, C-7, and also by the correlations of $\mathrm{H}-8$ with C-10, C-7, and C-10. The C-8/C-7/C-10 linkage was confirmed by the correlation of $\mathrm{H}-8$ with $\mathrm{C}-7$ and $\mathrm{C}-10$. The linkage $\mathrm{C}-2 / \mathrm{C}-3$ was secured by the correlations between $\mathrm{H}-1$ and $\mathrm{C}-2, \mathrm{C}-3$ and suggested the overall planar structure $\mathbf{1}$.

The $5 E, 7 Z$ stereochemistry of the double bonds were deduced from the ${ }^{13} \mathrm{C}$ NMR chemical shift, ${ }^{1} \mathrm{H}-{ }^{1} \mathrm{H}$ coupling constants, $1 \mathrm{D}$ NOE and 2D NOE (Table S1). Many trials were carried out to crystallize compound $\mathbf{1}$ from different solvents at low temperature, but all failed. In order to investigate the stereochemistry of compound $\mathbf{1}$, we applied the empirical rules of (Mynderse and Faulkner 1975; Crews et al., 1974).

We noticed that the $\mathrm{C}-3$ and $\mathrm{C}-4$ chiral centers of compound 1 must be assigned $\left(3 R^{*}, 4 S^{*}\right)$ according to the previous rules, as C-3 was found to possess $\delta_{\mathrm{C}}=25.1$ and $\delta_{\mathrm{H}}=1.77 \mathrm{ppm}$ and this fits the chemical shift range reported in the previous rules for the $\left(3 R^{*}, 4 S^{*}\right)$ stereochemistry of these compounds. The suggested structure of compound $\mathbf{1}$ was found be not similar to compound $\mathbf{5}\left(3 R^{*}, 4 R^{*}\right)$ (Table $\left.\mathrm{S} 2\right)$. However, the difference in ${ }^{1} \mathrm{H}$ chemical shift and the strong negative sign of the optical rotation of compound $\mathbf{1}\left([\mathrm{a}]^{25} \mathrm{D}=-92.0^{\circ}\right)$ and the positive sign of compound $6\left([a]^{25} \mathrm{D}=+5.1^{\circ}\right)$, strongly supported the suggestion that compound $\mathbf{1}$ is a diastereoismer to that of the previously reported compound $\mathbf{6}$ at C-3 and C-4. The $3 S^{*}, 4 R^{*}$ relationship at C-3 and C-4 was reinforced by $1 \mathrm{D}$ and $2 \mathrm{D}$ NOE experiments. Weak NOE effects between $\mathrm{H}-4$ and $\mathrm{H}_{3}-9$ were observed, confirming a relative $\left(R^{*}\right)$-configuration for the $\mathrm{C}-4$ chiral center. Compound $\mathbf{1}$, which had a negative optical rotation, $[\mathrm{a}]^{25} \mathrm{D}-92.0\left(\mathrm{c} 0.07, \mathrm{CHCl}_{3}\right)$, was thus shown to be a 3,4-erythro compound. However, we can conclude that ${ }^{1} \mathrm{H}$ shifts are not very discriminating as shown by comparing the data of compounds 5, $\mathbf{6}$ and $\mathbf{1}$. Hence, the ${ }^{13} \mathrm{C}$ NMR values are more useful for establishing the threo (28 ppm) versus erythro (25 ppm) relationship of substituents at C-3 and C-4 (Crews 1977).

We also isolated from this algal species the previously reported metabolites $\mathbf{2 , 3}$ and $\mathbf{4}$ (Crews 1977). We carried out a full investigation of the spectroscopic data of these compounds in the course of this work. Our isolation of compounds " 2 ", " 3 " and " 4 " were found to possess the same physical and spectroscopic data as reported in the literature (Mynderse and Faulkner 1975). 1D and 2D NOE experiments on compounds 2, 3 and 4 involving the protons of the methyl group (H-9) at 1.75, 1.77 and 1.78 gave weak enhancements or even no enhancements of the protons at $\delta 4.59(\mathrm{H}-4), \delta 4.53(\mathrm{H}-4)$ and $\delta$ 
$4.58(\mathrm{H}-4)$, respectively. This suggested that this methyl group and the proton attached to the chloromethine group at C-4 are directed to the opposite face of the molecule. Our data were found to obey the empirical rules (Crews 1977), but to some extent contradicts (Mynderse and Faulkner 1975) as they mainly depended only on the ${ }^{1} \mathrm{H}$ NMR chemical shifts of $\mathrm{H}_{3}-9$ beside the sign of the optical rotation to determine the stereochemistry of the chiral centers at C-3 and C-4 of the halogenated monoterpene compounds. For example, of two compounds with $\mathrm{H}_{3}-9$ in the same chemical shift range and with the same sign of optical rotation, one was assigned $3 R^{*}, 4 \mathrm{~S}^{*}$ and the other assigned $3 \mathrm{R}^{*}, 4 \mathrm{R}^{*}$ by (Mynderse and Faulkner). The ${ }^{13} \mathrm{C}$ NMR of compound 2 was at $\delta 25.6$, consistant with an erythro relationship of substituents at C-3 and C-4, and consistant with previous isolates of the compound (Mynderse and Faulkner 1975). Because there were no ${ }^{13} \mathrm{C}$ NMR data published in the previous literature (Mynderse and Faulkner 1975) for compound 3, we recorded and assigned those data here as part of this study (Table S6).

The isolated compounds were evaluated for their biological activity in several systems. Compound 1 was found to have cytotoxic activity $\left(\mathrm{IC}_{50}=4 \mu \mathrm{g} / \mathrm{ml}\right)$ to a human lung cancer cell line (NCI-H460) and the mouse neuro-2a neuroblastoma cell line. Upon testing these compounds in a sodium channel modulation assay, none of the compounds were found to have blocking or activating activity (data not shown). Compounds $\mathbf{3}$ and $\mathbf{4}$ were found to have cytotoxic activity in human colon cancer (CFU) cell lines ( $\mathrm{IC}_{50} 1.3 \mu \mathrm{g} / \mathrm{ml}$ ). None of these metabolites were active as sodium channel blockers or activators (Halogenated monoterpenes have not previously been evaluated for this bioactivity).

\section{Experimental}

\subsection{General Experimental Procedures}

Optical rotations were measured on a Perkin-Elmer 141 polarimeter. IR and UV spectra were recorded on Nicolet 510 and Beckman DU640B spectrophotometers, respectively. NMR spectra were recorded on a Bruker DPX400 spectrometer, with the solvent $\left(\mathrm{CDCl}_{3}\right.$ at $\left.\delta_{\mathrm{C}} 77.2, \delta_{\mathrm{H}} 7.26\right)$ used as an internal standard. Mass spectra were recorded on a Kratos MS50TC mass spectrometer, and HPLC isolations were performed using Waters Millipore model 515 pumps and a Waters 969 diode array detector.

\subsection{Algal Collection}

The marine brown alga Plocamium cartilagineum (voucher specimen available from WHG as collection number ZAT-26 -93) was collected intertidally by hand from South Africa eastern coast. The material was stored in 2-propanol at $-20{ }^{\circ} \mathrm{C}$ until extraction.

\subsection{Extraction and Isolation}

Approximately $47 \mathrm{~g}$ (dry wt.) of the Plocamium cartilagineum was extracted repeatedly with 2:1 $\mathrm{CH}_{2} \mathrm{Cl}_{2} / \mathrm{MeOH}$ to produce $2.8 \mathrm{~g}$ of crude organic extract. The crude extract (1.5) g was subjected to Si vacuum liquid chromatography (VLC, hexanes/EtOAc/MeOH) to produce 9 chemically distinct fractions. The fraction eluting with $100 \%$ hexanes $(1.073 \mathrm{gm})$ was subjected to normal phase HPLC (0-30\% ethyl acetate/hexanes) dual silica, Phenomenex 
Luna 10u Silica $250 \times 4.6 \mathrm{~mm}$ to yield $540 \mathrm{mg}$ of compound 3 and $60 \mathrm{mg}$ of compound 4,2 $\mathrm{mg}$ of compound $\mathbf{2}$ and $4 \mathrm{mg}$ of compound $\mathbf{1}$.

Compound 1-Colorless oil; [a $]^{25}{ }_{\mathrm{D}}-92.0\left(\mathrm{c} 0.07, \mathrm{CHCl}_{3}\right)$; UV $\left(\mathrm{CHCl}_{3}\right)_{\max } 242$ ( 3623) nm; IR (neat) 2923, 2853, 1459, 1375, 1215, 961, 932, 819, 749, $720 \mathrm{~cm}^{-1 ; 1} \mathrm{H}$ NMR and ${ }^{13} \mathrm{C}$ NMR (400 MHz, $\mathrm{CDCl}_{3}$ ) see Tables S1, S2 and S3; HRCIMS showed an ion at m1z $305.93079[\mathrm{M}]^{+}$for a molecular formula of $\mathrm{C}_{10} \mathrm{H}_{11} \mathrm{Cl}_{5}$, and therefore possessed three degrees of unsaturation. (Calculated mass is 306 for $\mathrm{C}_{10} \mathrm{H}_{11} \mathrm{Cl}_{5}$ ).

Compound 2-Colorless oil; [a $]^{25} \mathrm{D}-11.0\left(c 0.1, \mathrm{CHCl}_{3}\right)$ (literature - 4.4 Mynderse and Faulkner 1975) ${ }^{1} \mathrm{H}$ and ${ }^{13} \mathrm{C}$ NMR data see Table $\mathrm{S} 4$ and Table S5; with remaining physical and spectroscopic properties identical to those previously reported (Mynderse and Faulkner 1975).

Compound 3-Colorless oil; [a $]^{25} \mathrm{D}-26.0\left(\mathrm{c} 0.1, \mathrm{CHCl}_{3}\right)$ literature - 22.9 (Mynderse and Faulkner 1975) UV $\left(\mathrm{CHCl}_{3}\right)_{\max } 248$ ( ع 1973) nm; IR (neat) 3086, 2990, 2931, 1617, 1577, 1448, 1379, 1207, 1052, 964, 936, 854, 721 $\mathrm{cm}^{-1 ; 1} \mathrm{H}$ NMR and ${ }^{13} \mathrm{C}$ NMR data see Table S6 and Table S7; HRCIMS $\mathrm{m} / z$ [M] 383.8398 (Calculated mass is 384 for for $\mathrm{C}_{10} \mathrm{H}_{11} \mathrm{BrCl}_{5}$ ).

Compound 4-Colorless oil; [a $]^{25} \mathrm{D}-37.7\left(c 0.07, \mathrm{CHCl}_{3}\right)$ literature - 46.0 (Mynderse and Faulkner 1975) ${ }^{1} \mathrm{H}$ and ${ }^{13} \mathrm{C}$ NMR data see Table S8; with remaining physical and spectroscopic properties identical to those previously reported (Mynderse and Faulkner 1975).

\subsection{Cytotoxicity against $\mathrm{NCl}-\mathrm{H} 460$ human lung cancer and neuro-2a neuroblastoma cell line (Alley et al., 1988)}

Cytotoxicity was measured to NCI-H460 human lung tumor cells and mouse neuro-2a blastoma cells using the method of the method of Alley et al. (1988) with cell viability being determined by MTT reduction. Cells were seeded in 96-well plates at 5000 and 8000 cells/ well in $180 \mu \mathrm{l}$ for $\mathrm{H} 460$ and neuro-2a cells, respectively. Twenty-four hours later, the test chemical dissolved in DMSO and diluted into medium without fetal bovine serum was added at $20 \mu \mathrm{g} / \mathrm{well}$. Final DMSO concentration was less than $1 \%$ (v/v). After 48 hours, the medium was removed and cell viability determined.

\subsection{Sodium channel modulation (Manger and Leja 1995)}

Isolated compounds were evaluated for their capacity to either activate or block sodium channels using the following modifications to the cell-based bioassay of Manger and Leja (1995). Twenty-four hours prior to chemical testing, mouse neuro-2a blastoma cells were seeded in 96-well plates at $8 \times 10^{4}$ cells/well in a volume of $200 \mu$ l. Test chemicals dissolved in DMSO were serially diluted in medium without fetal bovine serum and added at $10 \mu \mathrm{l} /$ well. Final DMSO concentration was less than $1 \%$ (v/v). Plates to evaluate sodium channel activating activity received $20 \mu \mathrm{l} /$ well of either a mixture of $3 \mathrm{mM}$ ouabain and 0.3 $\mathrm{mM}$ veratridine (Sigma Chemical Co.) in $5 \mathrm{mM} \mathrm{HCl}$ in addition to the test chemical. Plates were incubated for $18 \mathrm{hr}$ and results compared to similarly treated solvent controls with 10 $\mu \mathrm{l}$ medium added in lieu of the test chemical., The sodium channel activator brevetoxin 
PbTx-1 (Calbiochem) was used as the positive control and added at $10 \mathrm{ng} / \mathrm{well}$ in $10 \mu \mathrm{l}$ medium. Sodium channel blocking activity was assessed in a similar manner except that ouabain and veratridine were 5.0 and $0.5 \mathrm{mM}$, respectively, and the sodium channel blocker saxitoxin (Calbiochem) was used as the positive control. Plates were incubated for approximately 22 hour.

\section{Conclusions}

One new halogenated monoterpene [(-)-(5E,7Z)-3,4,8-trichloro-7-dichloromethyl-3methyl-1,5,7-octatriene] in addition to three known compounds were isolated from the red alga Plocamium cartilagineum collected by hand from the eastern coast of South Africa. Structures of these compounds were determined by spectroscopic methods (UV, IR, LRMS, HRMS, 1D NMR and 2D NMR). Compound $\mathbf{1}$ has cytotoxic activity against human lung cancer (NCI-H460) and mouse neuro-2a cell lines ( $\mathrm{IC}_{50} 4 \mu \mathrm{g} / \mathrm{ml}$ ). Compound 3 and compound $\mathbf{4}$ were found to have cytotoxic activity against human leukemia and human colon cancers $\left(\mathrm{IC}_{50} 1.3 \mu \mathrm{g} / \mathrm{ml}\right)$. None of these metabolites were active as sodium channel blockers or activators (Halogenated monoterpenes have not previously been evaluated for this bioactivity).

\section{Supplementary Material}

Refer to Web version on PubMed Central for supplementary material.

\section{Acknowledgments}

Funding

This work was supported by the National Institute of Health (GM 63554 and CA52955)

We gratefully acknowledge Jeff. Moore (Chemistry Department, OSU) for mass spectral data, the Government of South Africa for permission to make these collections. Financial support for this work came from the National Institute of Health (GM 63554 and CA52955).

\section{References}

Abreu PM, Galindro JM. A new polyhalogenated epoxymonoterpene from Plocamium cartilagineum. Ind J Chem. 1998; 37B:610-611.

Abreu, Pedro M., Galindro, Jose M. Polyhalogenated Monoterpenes from Plocamium cartilagineum from the Portuguese Coast. J Nat Prod. 1996; 59:1159-1162.

Alley MC, Scudiero DA. Feasibility of drug screening with panels of human tumor cell lines using a microculture tetrazolium assay. Cancer Research. 1988; 48:589-601. [PubMed: 3335022]

Argandona VH, Rovirosa J, San-Martin A, Riquelme A, Diaz-Marrero AR, Cueto M, Darias J, Santana O, Guadano A, Gonzalez-Coloma A. Antifeedant Effects of Marine Halogenated Monoterpenes. J Agr Food Chem. 2002; 50:7029-7033. [PubMed: 12428955]

Blunt JW, Bowman NJ, Munro MHG, Parsons MJ, Wright GJ, Kon YK. Polyhalogenated Monoterpenes of the New Zealand Marine Red Alga Plocamium cartilagineum. Aust J Chem. 1985; 38:519-25.

Burreson BJ, Woolard FX, Moore RE. Evidence for the biogenesis of halogenated myrcenes from the red alga Chondrococcus hornemanni. Chemistry Letters. 1975; 11:1111-14.

Capon RJ, Engelhardt LM, Ghisalberti EL, Jefferies PR, Patrick VA, White AH. Structural studies of polyhalogenated monoterpenes from Plocamium species. Aust J Chem. 1984; 37:537-544. 
Vogel CV, Pietraszkiewicz H, Sabry OM, Gerwick WH, Valeriote FA, Vanderwal CD. Enantioselective Divergent Syntheses of Several Polyhalogenated Plocamium Monoterpenes and Evaluation of Their Selectivity for Solid Tumors. Angewandte Chemie. 2014; 126(45):12401-12405.

Crews P, Kho-Wiseman E, Cartilagineal. An Unusual Monoterpene Aldehyde from Marine Alga. J Org Chem. 1974; 39:3303-3304.

Crews P, Naylor S, Hanke FJ, Hogue ER, Kho E, Braslau R. Halogen Regiochemistry and Substituent Stereochemistry Determination in Marine Monoterpenes by ${ }^{13}$ C NMR. J Org Chem. 1984; 49:1371-1377.

Crews P, Ourers BL, Naylor S, Clason EL, Jacobs RS, Staal GB. Bio-active monoterpenes from red seaweeds. Phytochem. 1984; 23:1449-51.

Crews, Phillip. Monoterpene Halogenation by the Red Alga Plocamium oregonum. J Org Chem. 1977; 42:2634-6. [PubMed: 874621]

Inés CD, Argandoña VH, Rovirosa J, San-Martín A, Díaz-Marrero AR, Cueto M, González-Coloma A. Cytotoxic activity of halogenated monoterpenes from Plocamium cartilagineum. Zeitschrift für Naturforschung C. 2004; 59:339-344.

Fuller RW, Cardellina JH II, Kato Y, Brinen LS, Clardy J, Snader KM, Boyd MR. A Pentahalogenated Monoterpene from the Red Alga Portieria hornemannii Produces a Novel Cytotoxicity Profile against a Diverse Panel of Human Tumor Cell Lines. J Med Chem. 1992; 35:3007-3011. [PubMed: 1501227]

Gao D, Okuda R, Lopez-Avila V. Supercritical fluid extraction of halogenated monoterpenes from the red alga Plocamium cartilagineum. Journal of AOAC International. 2001; 84:1313-133. [PubMed: 11601448]

Gerwick WH, Tan LT, Sitachitta N. Nitrogen-containing metabolites from marine cyanobacteria. Alkaloids. 2001; 57:75-184. [PubMed: 11705123]

Gonzalez AG, Arteaga JM, Martin JD, Rodriguez ML, Fayos J, Martinez-Ripolls M. Two new polyhalogenated monoterpenes from the red alga Plocamium cartilagineum. Phytochemistrry. 1978; 17:947-8.

Higgs MD, Vanderah DJ, Faulkner DJ. Polyhalocenated monoterpenes from Plocamium cartilagineum from the British coast. Tetrahedron. 1977; 33:2775-80.

Manger RL, Leja LS. Detection of sodium channel toxins: directed cytotoxicity assays of purified ciguatoxins, brevetoxins, saxitoxins, and seafood extracts. Journal of AOAC International. 1995; 78:521-527. [PubMed: 7756868]

Mynderse JS, Faulkner DJ. Violacene a Polyhalogenated Monocyclic Monoterpene from the Red Alga Plocamium uioluceum. JACS. 1974; 96:6771-6772.

Mynderse JS, Faulkner DJ. Polyhalogenated monoterpenes from the red alga Plocamium cartilagineum. Tetrahedron. 1975; 31:1963-1967.

Naylor S, Hanke FJ, Manes LV, Crews P. Chemical and biological aspects of marine monoterpenes. Prog Chem Org Nat Prod. 1983; 44:189-241.

Norton RS, Warren RG, Wells RJ. Three new polyhalogenated monoterpenes from Plocamium species. Tetrahedron Lett. 1977; 18:3905-3908.

Ortega MJ, Zubia E, Salva J. A New Cladiellane Diterpenoid from Eunicella labiata. J Nat Prod. 1997; 60:482-484. [PubMed: 9213585]

Palma R, Edding M, Rovirosa J, San-Martín A, Argandoña VH. Effect of photon flux density and temperature on the production of halogenated monoterpenes by Plocamium cartilagineum (Plocamiaceae, Rhodophyta). Zeitschrift für Naturforschung C. 2004; 59:679-683.

Rovirosa J, Soler A, Blanc V, Leon R, San-Martin A. Bioactive monoterpenes from antarctic Plocamium cartilagineum. Journal of the Chilean Chemical Society. 2013; 58:2025-2026.

San-Martin A, Rovirosa J. Variations in the Halogenated Monoterpene Metabolites of Plocamium cartiagineum of the Chilean Coast. Biochem System Ecol. 1986; 14:459-61.

Thomas SG, Beveridge AA. The novel marine natural product plocamadiene a causes histamine release from mast cells of the guinea-pig and rat in vitro. Clin Exp Pharm Phys. 1993; 20:223-9.

Young RM, Von Salm JL, Amsler MO, Lopez-Bautista J, Amsler CD, McClintock JB, Baker BJ. Sitespecific variability in the chemical diversity of the Antarctic red alga Plocamium cartilagineum. Marine drugs. 2013; 11:2126-2139. [PubMed: 23771046] 
Watanabe K, Miyakado M, Ohno N, Okada A, Yanagi K, Moriguchi K. A polyhalogenated insecticidal monoterpene from the red alga, Plocamium telfairiae. Phytochemisty. 1989; 28:77-78.

Wessels, Matthias, Koenig, Gabriele M., Wright, Anthony D. New Natural Product Isolation and Comparison of the Secondary Metabolite Content of Three Distinct Samples of the Sea Hare Aplysia dactylomela from Tenerife. J Nat Prod. 2000; 63:920-928. [PubMed: 10924166]

Wright AD, Coll JC, Price IR. Tropical marine algae, vii. The chemical composition of marine algae from north queensland waters. J Nat Prod. 1990; 53:845-861. 


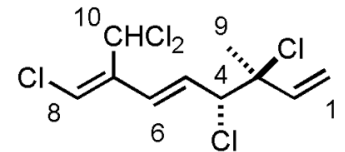

1<smiles>C[C@](Cl)(/C=C/Br)C(Cl)/C=C/C(Cl)=C\Cl</smiles>

4

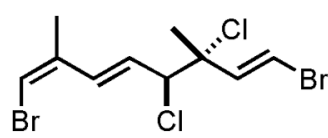

2

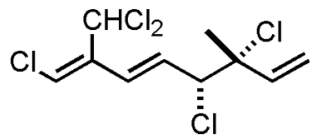

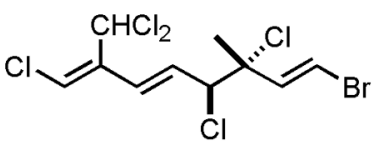

3

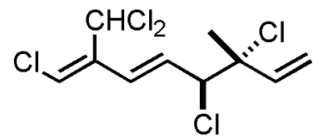

6

Figure 1.

Halogenated monoterpenes from $P$. cartilagineum. 


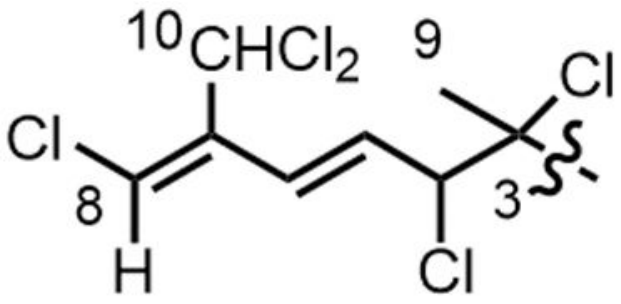

b



a

Figure 2.

Partial structures of compound 1. 